\title{
薄層近似を用いた強い摇らぎにおけるビーム波の強度変動解析
}

\author{
豊田 雅宏 \\ (独) 情報通信研究機構（广184-8795 東京都小金井市貫井北町4-2-1）
}

\section{Analysis of Wave Front Fluctuations in Strong Turbulence Using Thin Phase Screen Approximation}

\author{
Masahiro TOYODA \\ National institute of information and communication technology, 4-2-1 Nukuikita-machi, Koganei-shi, Tokyo 184-8795
}

(Received September 15, 2011)

\begin{abstract}
This paper reports the beam wave fluctuations caused by strong atmospheric turbulence. These beam wave fluctuations are estimated by numerical calculations carried out using moment equation analysis with thin phase screen approximation. The scintillation index for a plane wave is calculated as a function of a parameter concerning the intensity of atmospheric turbulence, and the result is in good agreement with previous studies. Transmission of the beam radius dependence of a scintillation index is calculated using the first and second moments of wave intensity. The largest scintillation index is obtained when the beam radius size equals $(\lambda z / 2 \pi)^{1 / 2}$. The scintillation index of a beam wave is also evaluated using the Rytov approximation method, which is based on perturbation analysis.
\end{abstract}

Key Words: Atmospheric turbulence, Laser beam, Random medium, Wireless optical communication

1. はじめに

ランダム媒質中の波動伝搬に関しては，半世紀以上に 渡る研究の中で, 各種の統計的, 理論的な検討や様々な 状況下での実験検証がなされてきた ${ }^{1}$ 。国内において も, 特殊な形状のビーム伝搬に関する実験的な検討が近 年積極的に行われている2,3)。これまでに積み上げられ た検討の中で, 波動摇動の解析法としては, 摇動を摂動 として扱った近似解法 (Rytov法) が最も一般的な大気摇 らぎの解析法として知られている ${ }^{1)}$. Rytov法は摂動解析 に中心極限定理を適用し, 波動強度の確率密度分布を導 いた半経験的な解析法であり, 直観的な理解が容易なこ とに加えて, 多くの実験結果の裏付けから支持されてい る。その適用範囲は弱い摇らぎと呼ばれるケースに限定 され，摂動解析の範囲を超えた強い摇らぎについては, 波動方程式の近似解法, Huygensの原理に基づく方法, エネルギー保存則を用いた手法，あるいは，経験的に作 られたモデル, さらに, 計算機シミュレーションを組み 合わせた方法等が提案されてきた。

それらの中で, 波動の確率モーメントから摇動の統計 量を導く方法(モーメント法)に対し, 解析過程の厳密性 から，なお高い信頼が寄せられている4)。このモーメン ト法については, 筆者による先の論文にて, 弱い摇動に 対してRytov法との比較が記されている5). しかしながら 現状において，ある特殊な場合(媒質摇らぎの最小サイ ズであるインナースケールよりビーム径が細い場合)を
除いて，強い摇らぎに関する解析理論が確立されてはい ない ${ }^{6)}$ その最大の理由は，波動の伝搬に伴う多重散乱 現象を数式にて表現し, さらに，その数式を解析的に解 くことが困難なためである.

強い摇動の領域における強度分散の測定としては，平

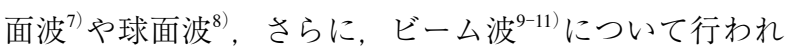
ており，摇らぎの強度に対する波動強度分散の飽和の状 況が波動の形状に依らず，ほぼ類似した結果として報告 されている。これは，文献10）については，波長が $0.63 \mu \mathrm{m}$ のビームに対して送信口径が $0.3 \mathrm{~m}$ と大きく，文 献11）では広がり角を3.9 $\mathrm{mrad}$ 広く設定しており，い ずれもビーム伝送の構成からの帰結と考えられる。近 年, ビーム波の強度分散の測定実験が行われ ${ }^{12)}$, 飽和時 の分散值が経験的なモデルによる推算と合致したとの報 告がなされている。また, これまでの理論検討の中で, 強度分散のビーム径依存性を検討した例は，筆者の知る ところ，文献13）による一例であり，これは，媒質摇ら ぎの相関長に対するビーム径比を二值に設定し解析した もので, 球面波に近い状況でのビーム伝送を評価したも のである。

これらの，未だ完結を得ていない強い摇らぎ状況下で の波動摇動について理解を深めることは, 自然現象の解 明のみならず，利用に向けての工学的な側面からも有用 と考える。本論では強い摇動を受けたビーム波の強度変 動について，モーメント法による解析と数值計算の結果 を述べる，強い摇動を受けたビーム波の強度モーメント 
をビーム径に対する依存性を含めて解析的に調べること が目的である。波動のモーメント解に対して，摇らぎが 生起する領域を薄い層に限定した近似(薄層近似)を利用 して解析を進め, 得られた解に対して数值計算を試み た。これまでに，薄層近似を用いた波動モーメントの一

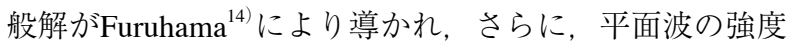
分散が数值計算により求められている ${ }^{15,16)}$. これらの先 行文献を基に，第2章にて，ビーム波の薄層近似による 波動強度モーメントの導出について記す。第3章では, 強い摇らぎにおけるビーム波の平均強度とシンチレー ションインデックスの数值計算結果を示す。 その中で, Rytov近似により算出した結果との比較を行い, 両解析 法の摇らぎ強度の適用範囲についても記す。

\section{2. 薄層近似によるビーム波の強度モーメント}

屈折率がランダムに摇らいでいる媒質中の波動は, 偏 光に関する影響を無視できることからHelmholtz型の方 程式

$$
\nabla^{2} U+k^{2}[1+\varepsilon(\boldsymbol{r})] U=0
$$

を満たす。ここで, $U$ は複素波動, $k$ は光波の波数, 位 置 $\boldsymbol{r}$ での屈折率 $[1+\varepsilon(\boldsymbol{r})]^{1 / 2}$ に対して $\varepsilon(\boldsymbol{r})$ は媒質摇らぎに よる微小な変動分である。波動モーメント導出における 媒質摇らぎの仮定は，媒質の屈折率の摇らぎが一様で滑 らかであり，3次元空間のどこについても同じ性質であ る等方的とする。時間によって媒質ゆらぎの統計的性質 が変化しない定常性をもち, さらに, 吸収損失の無い媒 質を仮定する。 大気伝搬の場合には，乱流媒質である大 気の屈折率変動が微小で, 波動の前方散乱が卓越し後方 散乱を無視できる。このため, 式(1)から特定の方向に 伝搬する波動を抽出できる。このことは波動方程式の Fresnel近似 (近軸式)に相当し，伝搬方向に関する波動関 数の2回微分項を微小として無視した放物型の偏微分方 程式を適用できる。それにより， $z$ 軸方向へ伝搬する3次 元空間座標 $\boldsymbol{y}$ の波動関数(波動の複素振幅) $\psi(\boldsymbol{y})$ は

$$
\left[2 i k \frac{\partial}{\partial z}-\frac{\partial^{2}}{\partial \bar{y}^{2}}-k^{2} \varepsilon(\boldsymbol{y})\right] \psi(\boldsymbol{y})=0
$$

を満たす，ここでは，座標系の定義として $\boldsymbol{y}=(\bar{y}, z)$, 同 様に $\boldsymbol{x}=(\overline{\boldsymbol{x}}, z)$ とする. 上線は $z$ 軸に垂直な面内に有る成 分を表す。そして, $\psi(\boldsymbol{y})$ に対して複素共役な波動関数 を $\psi^{*}(\boldsymbol{x})$ と置くと, 波動関数の多重相関関数である任意 次数の結合確率モーメントは

$$
M_{m n} \equiv\left\langle\psi^{*}\left(\boldsymbol{x}_{1}\right) \psi^{*}\left(\boldsymbol{x}_{2}\right) \cdots \psi^{*}\left(\boldsymbol{x}_{m}\right) \psi\left(\boldsymbol{y}_{1}\right) \psi\left(\boldsymbol{y}_{2}\right) \cdots \psi\left(\boldsymbol{y}_{n}\right)\right\rangle
$$

と定義される。右辺の記号〈・〉は統計平均を表す。そし て, 波動の前方散乱の仮定により波動強度のN次モーメ ントの満たす波動方程式は

$$
\left[k^{-1} \frac{\partial}{\partial z}+i k^{-2} \sum_{j=1}^{N}\left(\frac{\partial}{\partial \bar{r}_{j}} \cdot \frac{\partial}{\partial \bar{\rho}_{j}}\right)+\sum_{j=1}^{N} V\left(\overline{\boldsymbol{r}}_{j}\right)+\sum_{n>m}^{N} V_{I}\left(\overline{\boldsymbol{r}}_{m}, \overline{\boldsymbol{r}}_{n}, \overline{\boldsymbol{\rho}}_{m n}\right)\right]
$$

$$
\times M_{N N}\left(\overline{\boldsymbol{r}}_{1}, \cdots, \overline{\boldsymbol{r}}_{N}, \overline{\boldsymbol{\rho}}_{1}, \cdots, \bar{\rho}_{N}, z\right)=0
$$

と導ける ${ }^{6)}$ 。ここでは相対座標

$$
\begin{aligned}
& \overline{\boldsymbol{r}}_{m}=\overline{\boldsymbol{y}}_{m}-\overline{\boldsymbol{x}}_{m} \\
& \bar{\rho}_{m}=\left(\overline{\boldsymbol{y}}_{m}+\overline{\boldsymbol{x}}_{m}\right) / 2
\end{aligned}
$$

を導入している。 $V(\boldsymbol{r})$ は位相構造関数であり， $V_{I}$ は $\bar{\rho}_{m n}=\bar{\rho}_{m}-\bar{\rho}_{n}$ として

$$
\begin{aligned}
& V_{I}\left(\overline{\boldsymbol{r}}_{m}, \overline{\boldsymbol{r}}_{n}, \overline{\boldsymbol{\rho}}_{m n}\right) \\
& =V\left[\overline{\boldsymbol{\rho}}_{m n}-\left(\overline{\boldsymbol{r}}_{m}+\overline{\boldsymbol{r}}_{n}\right) / 2\right]+V\left[\overline{\boldsymbol{\rho}}_{m n}+\left(\overline{\boldsymbol{r}}_{m}+\overline{\boldsymbol{r}}_{n}\right) / 2\right] \\
& \quad-V\left[\overline{\boldsymbol{\rho}}_{m n}-\left(\overline{\boldsymbol{r}}_{m}-\overline{\boldsymbol{r}}_{n}\right) / 2\right]-V\left[\overline{\boldsymbol{\rho}}_{m n}+\left(\overline{\boldsymbol{r}}_{m}-\overline{\boldsymbol{r}}_{n}\right) / 2\right]
\end{aligned}
$$

である。式(4)の位相構造関数項全体としては，伝搬路 上の媒質摇らぎによって波動に及んだ影響の受光面上で の累積と捉えられる。 $V(\boldsymbol{r})$ は対象となる2点間の距離 $|\boldsymbol{r}|$ と, 屈折率摇らぎのインナースケール $l_{0}$, および, アウ タースケール $L_{0}$ との大小関係によって

$$
\begin{gathered}
V(\boldsymbol{r}) \simeq 1.65 C_{n}{ }^{2} k^{-1} l_{0}^{-1 / 3}|k \boldsymbol{r}|^{2} \quad|\boldsymbol{r}| \ll l_{0} \\
V(\boldsymbol{r}) \simeq 1.46 C_{n}{ }^{2} k^{-2 / 3}|k \boldsymbol{r}|^{5 / 3} \quad l_{0} \ll|\boldsymbol{r}| \ll L_{0}
\end{gathered}
$$

と二種に分類される ${ }^{17)}$. ビーム波の伝搬では式(7a)の条 件 $|\boldsymbol{r}| \ll l_{0}$ はビーム径が $l_{0}$ と比して細い場合に相当し, 式 （7b）は通常のビーム伝送の場合である。上記の $V(\boldsymbol{r})$ は屈 折率摇らぎの3次元パワースペクトル $\Phi_{n}$ がKolmogorov ス ペクトル

$$
\Phi_{n}(\kappa)=0.033 C_{n}^{2} \kappa^{-11 / 3} \exp \left(\frac{-\kappa^{2}}{\kappa_{m}^{2}}\right)
$$

を有すとの仮定により導かれたものである。ここに， $C_{n}$ は屈折率構造定数, $\kappa$ は屈折率摇らぎの空間的な波数で あり， $\kappa_{m}=5.92 / l_{0}$ である.

ここで, Gaussianビームの伝搬を考え，摇らぎ媒質と 受光面の位置関係をFig. 1のように設定する。 $z$ 軸方向に 伝搬するビーム波について, 送信点を $z=0$, 受光面まで の伝搬長を $z$ とする。 $z_{0}$ はビームウエスト位置, $b$ はビー ムウエスト半径 (強度が1/e) である。摇らぎが無いと仮 定した自由空間伝搬時のビーム波の波動関数は

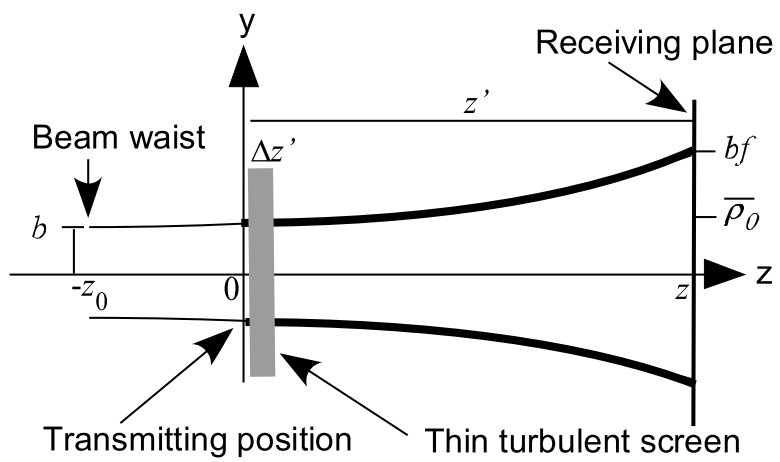

Fig. 1 A sketch of beam wave propagation through a thin turbulent screen. 
$\psi(\bar{y})=I_{0}^{1 / 2}\left(1-i \frac{z+z_{0}}{k b^{2}}\right)^{-1} \exp \left[-i k z-\frac{\bar{y}^{2}}{2 b^{2} f^{2}}\left(1+i \frac{z+z_{0}}{k b^{2}}\right)\right]$

と表せる. ここで， $I_{0}$ はビームウエストでの光軸上の波 動強度, また

$$
f^{2}=1+\frac{\left(z+z_{0}\right)^{2}}{k^{2} b^{4}}
$$

である。これにより，自由空間を伝搬したときの受光面 上での波動強度 1 次モーメントは

$$
\begin{aligned}
& M_{11}{ }^{0}(\overline{\boldsymbol{r}}, \overline{\boldsymbol{\rho}}, z) \\
& =I_{0} f^{-2} \exp \left[-\frac{\overline{\boldsymbol{\rho}}^{2}+\overline{\boldsymbol{r}}^{2} / 4}{b^{2} f^{2}}-i \frac{\left(z+z_{0}\right) \overline{\boldsymbol{r}} \cdot \overline{\boldsymbol{\rho}}}{k b^{4} f^{2}}\right]
\end{aligned}
$$

となる。 また, 波動強度の1次モーメントのFourier変換 $\tilde{M}_{11}{ }^{0}(\bar{s}, \bar{\lambda}, z)$ を用いて, 自由空間伝搬時の波動強度の2次 モーメントは

$$
M_{22}{ }^{0}(\overline{\boldsymbol{r}}, \bar{\rho}, z)
$$

$=(2 \pi)^{-8} \int_{-\infty}^{\infty} \iiint \prod_{j=1}^{2} d \bar{s}_{j} d \bar{\lambda}_{j} \tilde{M}_{11}{ }^{0}\left(\bar{s}_{j}, \bar{\lambda}_{j}, z\right) \exp \left[-i\left(\bar{s}_{j} \overline{\boldsymbol{r}}+\bar{\lambda} \bar{\lambda}_{j} \overline{\boldsymbol{\rho}}\right)\right]$

と表せる ${ }^{14)}$.

摇らぎ媒質を伝搬した波動の高次モーメントに関して は，式(4)にて位相構造関数をポテンシャルとし， $z$ を時 間に関する変数と見做すと多体のSchrödingerの波動方程 式と同形となることから, 量子力学分野にて見出された 手法を用いて解の導出が行われてきだ6). その解法に 倣って微分演算子を導入し, 波動強度の2次モーメント を式(4)から

$$
k^{-1} \frac{\partial}{\partial z} M_{22}(z)=\left(T_{2}-V_{2}\right) M_{22}(z)
$$

と置き換える。ここで,

$$
\begin{aligned}
& T_{2}=-i k^{-2}\left(\frac{\partial}{\partial \overline{\boldsymbol{r}}_{1}} \cdot \frac{\partial}{\partial \bar{\rho}_{1}}+\frac{\partial}{\partial \overline{\boldsymbol{r}}_{2}} \cdot \frac{\partial}{\partial \bar{\rho}_{2}}\right) \\
& V_{2}=V\left(\overline{\boldsymbol{r}}_{1}\right)+V\left(\overline{\boldsymbol{r}}_{2}\right)+V_{I}\left(\overline{\boldsymbol{r}}_{1}, \overline{\boldsymbol{r}}_{2}, \overline{\boldsymbol{\rho}}_{12}\right)
\end{aligned}
$$

である.この微分方程式の解は形式的に次の微積分形

$$
M_{22}(z)=P \exp \left[-k \int_{0}^{z} \hat{V}_{2}\left(-z^{\prime}\right) d z^{\prime}\right] \exp \left(k T_{2} z\right) M_{22}(0)
$$

で与えられる。ここで

$$
\hat{V}_{2}(z)=\exp \left(-k T_{2} z\right) V_{2} \exp \left(k T_{2} z\right)
$$

である。Pは任意の関数 $A(z), B(z)$ に対して

$$
P\left[A\left(z^{\prime \prime}\right) B\left(z^{\prime}\right)\right]= \begin{cases}A\left(z^{\prime \prime}\right) B\left(z^{\prime}\right) & \left(z^{\prime \prime}>z^{\prime}\right) \\ B\left(z^{\prime}\right) A\left(z^{\prime \prime}\right) & \left(z^{\prime \prime}<z^{\prime}\right)\end{cases}
$$

の交換関係を表し, 波動の多重散乱に伴って発生する位 相摇らぎの生起順序を含有させている。 そのため, 式 （16）をこれ以上書き下すことは出来ない. さらに解析を 進めるには式(16)に対し何等かの近似を施し $P$ にる交 換関係の制限を外す必要がある。ここでは，摇らぎ媒質
が薄い層状に分布するとの仮定(薄層近似)を適用す る ${ }^{14,16)}$ 。これにより, 波動強度の2次モーメントは摇ら ぎの無いときのモーメント $M_{22}{ }^{0}(z)$ を用いて

$$
M_{22}(z) \simeq \exp \left[-k \Delta z^{\prime} \hat{V}_{2}\left(-z^{\prime}\right)\right] M_{22}{ }^{0}(z)
$$

と表現できる。ここで， $\Delta z^{\prime}$ は摇らぎ薄層の厚さ， $z^{\prime}$ は薄 層から受光面までの距離である. 式(19)の関数形から分 かるように, 薄層が送信直後に有る場合 $\left(z^{\prime}=z\right) に$, 摇ら ぎ媒質の影響が最も大きく受光面上に現れ，薄層が受光 面に近づくに連れて摇らぎ媒質の影響が小さくなる。

そして, 式(12)の自由空間伝搬における波動強度の2 次モーメントを式(19)に代入すると

$$
\begin{aligned}
& M_{22}(z) \\
& \simeq(2 \pi)^{-8} \iiint \int \prod_{-\infty}^{\infty} d \bar{s}_{j} d \bar{\lambda}_{j} \tilde{M}_{11}{ }^{0}\left(\bar{s}_{j}, \bar{\lambda}_{j}, z\right) \exp \left[-i\left(\bar{s}_{j} \overline{\boldsymbol{r}}+\bar{\lambda}_{j} \bar{\rho}\right)\right] \\
& \quad \times \exp \left[-k \Delta z^{\prime} \hat{V}_{2}\left(-z^{\prime}\right)\right]
\end{aligned}
$$

が得られる。このランダム量が含まれた関数のモーメン 卜を求めるに当り, 演算子の特性関数を用いることで解 析を単純化できる。 なお, 量子力学におけるHamiltonian に相当する演算子を用いて波動強度モーメント解が Furuhamaにより求められているが(4)，薄層近似によりP の交換関係が外れているためHamilton演算子を導入せず とも解析を進めることができ，本論では，位相構造関数 全体に微分演算子を作用させる，より簡易な手法にて摇 動を組み入れたモデルを導く，始めに，演算子を

$$
\begin{aligned}
& \hat{\boldsymbol{r}}_{n}=\hat{\boldsymbol{r}}_{n}\left(-z^{\prime}\right)=\overline{\boldsymbol{r}}_{n}-i k^{-1} z^{\prime} \frac{\partial}{\partial \bar{\rho}_{n}} \\
& \hat{\boldsymbol{\rho}}_{n}=\hat{\boldsymbol{\rho}}_{n}\left(-z^{\prime}\right)=\overline{\boldsymbol{\rho}}_{n}-i k^{-1} z^{\prime} \frac{\partial}{\partial \overline{\boldsymbol{r}}_{n}}
\end{aligned}
$$

と設定し，その特性関数を

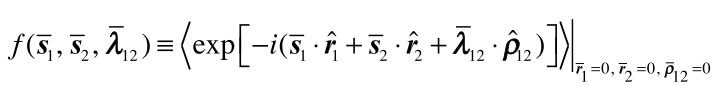

と定義する。ここで， $\hat{\rho}_{m n}=\hat{\rho}_{m}-\hat{\rho}_{n}$ であり，右端の記号は 演算後に各変数に 0 を代入する意である，任意の関数 $F(x)$ に対して, この特性関数を用いると

$$
\begin{aligned}
& \left.\left\langle F\left(\hat{r}_{1}, \hat{r}_{2}, \hat{\boldsymbol{\rho}}_{12}\right)\right\rangle\right|_{\bar{r}_{1}=0, \bar{r}_{2}=0, \bar{\rho}_{12}=0} \\
& =\left.F\left(\frac{\partial}{\partial \overline{\boldsymbol{s}}_{1}}, \frac{\partial}{\partial \overline{\boldsymbol{s}}_{2}}, \frac{\partial}{\partial \overline{\boldsymbol{\lambda}}_{12}}\right) f\left(\overline{\boldsymbol{s}}_{1}, \overline{\boldsymbol{s}}_{2}, \bar{\lambda}_{12}\right)\right|_{\bar{s}_{1}=0, \bar{s}_{2}=0, \bar{\lambda}_{12}=0} \\
& =\iiint \iiint d \overline{\boldsymbol{r}}_{1} d \overline{\boldsymbol{r}}_{2} d \overline{\boldsymbol{\rho}}_{12} F\left(\overline{\boldsymbol{r}}_{1}, \overline{\boldsymbol{r}}_{2}, \overline{\boldsymbol{\rho}}_{12}\right) G\left(\overline{\boldsymbol{r}}_{1}, \overline{\boldsymbol{r}}_{2}, \overline{\boldsymbol{\rho}}_{12}\right)
\end{aligned}
$$

が公式として成り立つ ${ }^{16)}$. 最右辺では $F(x)$ の直接的な関 数展開が不可な場合に対して, Green関数を用いた積分 表示を行っている。 このGreen関数には特性関数が組み 达まれ

$$
\begin{aligned}
& G\left(\overline{\boldsymbol{r}}_{1}, \overline{\boldsymbol{r}}_{2}, \overline{\boldsymbol{\rho}}_{12}\right) \\
& =(2 \pi)^{-6} \iiint \iiint \int d \overline{\boldsymbol{s}}_{1} d \overline{\boldsymbol{s}}_{2} d \overline{\boldsymbol{\lambda}}_{12} f\left(\overline{\boldsymbol{s}}_{1}, \overline{\boldsymbol{s}}_{2}, \overline{\boldsymbol{\lambda}}_{12}\right) \\
& \times \exp \left[i\left(\overline{\boldsymbol{r}}_{1} \cdot \overline{\boldsymbol{s}}_{1}+\overline{\boldsymbol{r}}_{2} \cdot \overline{\boldsymbol{s}}_{2}+\overline{\boldsymbol{\rho}}_{12} \cdot \overline{\boldsymbol{\lambda}}_{12}\right)\right]
\end{aligned}
$$


となる. 式(21)を用いて上述の特性関数, さらにGreen 関数を具体的に導くと

$$
\begin{gathered}
f\left(\overline{\boldsymbol{s}}_{1}, \overline{\boldsymbol{s}}_{2}, \overline{\boldsymbol{\lambda}}_{12}\right)=\exp \left[i z^{\prime} k^{-1}\left(\overline{\boldsymbol{s}}_{1}-\overline{\boldsymbol{s}}_{2}\right) \cdot \overline{\boldsymbol{\lambda}}_{12}\right] \\
G\left(\overline{\boldsymbol{r}}_{1}, \overline{\boldsymbol{r}}_{2}, \overline{\boldsymbol{\rho}}_{12}\right)=\left(\lambda z^{\prime}\right)^{-2} \delta\left(\overline{\boldsymbol{r}}_{1}+\overline{\boldsymbol{r}}_{2}\right) \exp \left[-\frac{i k}{2 z^{\prime}}\left(\overline{\boldsymbol{r}}_{1}-\overline{\boldsymbol{r}}_{2}\right) \cdot \overline{\boldsymbol{\rho}}_{12}\right]
\end{gathered}
$$

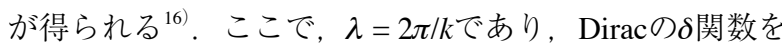
用いて位相構造関数形を規定している。そして，式(20) の波動強度2次モーメントに式(23)の公式を適用し, 式 (25), および, 式 $(26)$ の関係を用いると， $\bar{\rho}_{0}$ をビーム光 軸からの距離として

$$
\begin{aligned}
& \left\langle I\left(\bar{\rho}_{0}\right)^{2}\right\rangle=M_{22}(z) \\
& \simeq \int_{-\infty}^{\infty} \iiint \iint d \overline{\boldsymbol{r}}_{1} d \overline{\boldsymbol{r}}_{2} d \bar{\rho}_{12} \exp \left[-k \Delta z^{\prime} V_{2}\left(\overline{\boldsymbol{r}}_{1}, \overline{\boldsymbol{r}}_{2}, \overline{\boldsymbol{\rho}}_{12}\right)\right](2 \pi)^{-8} \\
& \quad \times \int_{-\infty}^{\infty} \iiint \prod_{j=1}^{2} d \bar{\lambda}_{j} d \bar{s}_{j} \tilde{M}_{11}{ }^{0}\left(\overline{\boldsymbol{s}}_{j}, \bar{\lambda}_{j}, z\right) \exp \left(-i \bar{\rho}_{0} \bar{\lambda}_{j}\right) G\left(\overline{\boldsymbol{r}}_{1}, \overline{\boldsymbol{r}}_{2}, \overline{\boldsymbol{\rho}}_{12}\right) \\
& =\left(\lambda z^{\prime}\right)^{-8} \iiint \iint_{-\infty}^{\infty} d \overline{\boldsymbol{r}}_{1} d \bar{\rho}_{12} \exp \left[-k \Delta z^{\prime} V_{2}\left(\overline{\boldsymbol{r}}_{1},-\overline{\boldsymbol{r}}_{1}, \overline{\boldsymbol{\rho}}_{12}\right)\right] \\
& \quad \times \int_{-\infty}^{\infty} \iiint \prod_{j=1}^{2} d \bar{r}_{j}^{\prime \prime} \bar{\rho}_{j}^{\prime \prime} M_{11}{ }^{0}\left(\bar{r}_{j}^{\prime \prime}, \bar{\rho}_{j}^{\prime \prime}, z\right) \\
& \quad \times \exp \left\{i k z^{\prime-1}\left[\bar{r}_{j}^{\prime \prime}\left(\bar{\rho}_{j}^{\prime \prime}+\overline{\boldsymbol{\rho}}_{12}\right)+\overline{\boldsymbol{r}}_{1}\left(\overline{\boldsymbol{\rho}}_{0}-\bar{\rho}_{j}^{\prime \prime}\right)\right]\right\}
\end{aligned}
$$

が得られる。ここでは，自由空間伝搬時の波動強度1次 モーメントのFourier逆変換を利用している。 そして, 次 の変数変換

$$
\begin{aligned}
& \bar{r}_{1}\left(\lambda z^{\prime}\right)^{-1 / 2}=\overline{\boldsymbol{s}} \\
& \bar{\rho}_{12}\left(\lambda z^{\prime}\right)^{-1 / 2}=\bar{\lambda} \\
& \bar{r}_{j}^{\prime \prime}\left(\lambda z^{\prime}\right)^{-1 / 2}=\bar{r}_{j} \\
& \bar{\rho}_{j}^{\prime \prime}\left(\lambda z^{\prime}\right)^{-1 / 2}=\bar{\rho}_{j}
\end{aligned}
$$

を式(27)へ施すと, ビーム光軸上での波動強度の2次 モーメントは

$$
\begin{aligned}
\left\langle I^{2}\right\rangle \simeq & \int_{-\infty}^{\infty} \iiint d \bar{s} d \bar{\lambda} \exp \left(-\eta f_{2}\right) \\
& \times \int_{-\infty}^{\infty} \iiint \prod_{j=1}^{2} d \bar{r}_{j} d \bar{\rho}_{j} M_{11}{ }^{0}\left[\left(\lambda z^{\prime}\right)^{1 / 2} \bar{r}_{j},\left(\lambda z^{\prime}\right)^{1 / 2} \bar{\rho}_{j}, z\right] \\
& \times \exp \left[i 2 \pi\left(\bar{r}_{j} \bar{\rho}_{j}+\bar{r}_{j} \bar{\lambda}-\overline{\boldsymbol{s}} \bar{\rho}_{j}\right)\right]
\end{aligned}
$$

と整理できる。ここに

$$
\begin{gathered}
\eta \equiv 1.46 C_{n}{ }^{2} k^{1 / 3}\left(2 \pi k z^{\prime}\right)^{v / 2} \Delta z^{\prime} \\
f_{2}=2|\bar{s}|^{v}+2|\bar{\lambda}|^{v}-|\bar{\lambda}+\bar{s}|^{v}-|\bar{\lambda}-\bar{s}|^{v}
\end{gathered}
$$

である。このvの值は媒質摇らぎのパワースペクトルの 形状によって異なり，式（8）に示したKolmogorovスペク トルの場合には $v=5 / 3$ となる。そして， $\bar{r}_{j}$ と $\bar{\rho}_{j}$ に関する 積分を実行すると $\left\langle I^{2}\right\rangle \simeq \frac{I_{0}^{2}}{f^{4}} \int_{-\infty}^{\infty} \iiint d \overline{\mathbf{s}} d \bar{\lambda} \exp \left(-\eta f_{2}\right)$

$$
\times \exp \left\{-\frac{\lambda z^{\prime}}{b^{2} f_{1}^{2}}\left[\frac{\overline{\boldsymbol{s}}^{2}}{4}+\bar{\lambda}^{2}+i\left(\frac{z+z_{0}}{k b^{2}}-\frac{k b^{2} f^{2}}{z^{\prime}}\right) \overline{\boldsymbol{s}} \cdot \bar{\lambda}\right]\right\}
$$

が得られる。ここで,

$$
f_{1}^{2}=1+\frac{\left(z+z_{0}-z^{\prime}\right)^{2}}{k^{2} b^{4}}
$$

である。波動強度の1次と2次のモーメントを用いて，波 動の規格化強度分散 $\sigma_{I}^{2}$ (シンチレーションインデック ス)が

$$
\sigma_{I}^{2}=\frac{\left\langle I^{2}\right\rangle-\langle I\rangle^{2}}{\langle I\rangle^{2}}=\frac{M_{22}(z)-M_{11}(z)^{2}}{M_{11}(z)^{2}}
$$

と表せる，波動強度の1次モーメントについては，位相 構造関数形が単純な形式となり, 2次モーメント導出と 同様に自由空間伝搬時の波動強度1次モーメントのFourier逆変換を用いて

$$
\begin{aligned}
& \left\langle I\left(\bar{\rho}_{0}\right)\right\rangle \simeq M_{11}\left(\bar{\rho}_{0}, z\right) \\
& =\frac{I_{0}}{f^{2}} \int_{-\infty}^{\infty} \int d \bar{s} d \bar{\lambda} \exp \left(-\eta \mid \bar{s}^{v}\right) \exp \left[i 2 \pi \bar{\rho}_{0} \bar{s}\left(\lambda z^{\prime}\right)^{-1 / 2}\right] \\
& \quad \times \exp \left\{-\frac{\lambda z^{\prime}}{b^{2} f_{1}^{2}}\left[\frac{\bar{s}^{2}}{4}+\bar{\lambda}^{2}+i\left(\frac{z+z_{0}}{k b^{2}}-\frac{k b^{2} f^{2}}{z^{\prime}}\right) \bar{s} \bar{\lambda}\right]\right\}
\end{aligned}
$$

と導ける ${ }^{18)}$.この波動強度の1次モーメントは，波動の 自己コヒーレンス関数に相当し，受光面上での平均強度 を表す。これらの各モーメントの関数形から $\eta$ の極大に て $\sigma_{I}^{2}$ が1に収斂することが示される。

\section{3. 数值計算}

3.1 ビーム平均強度

式(35)の波動強度の1次モーメント解，および，それ に対する数值計算の検証として，摇らぎ薄層にGaussian ビームを入射させたときの受光面上での強度分布を算出 した.この值は長時間露光時のビーム強度の平均に相当 し, ここでの長時間露光とは摇動のアンサンブル平均に 時間平均が一致するまでに露光した時間である。その時 間 $T$ は，主に大気の平均風速に依存し $T \gg 0.01 \mathrm{~s}$ とされ る $^{19)}$.

数值計算例として, 屈折率構造定数の二乗 $C_{n}{ }^{2}$ をパラ メータとしたときの薄層伝搬後のビーム波の強度分布を Fig. 2 に示す. Fig. 2の横軸 $\bar{\rho}_{0}$ は受光面上でのビーム光軸 からの距離であり，縦軸はビームウエストでのビーム光 軸上の波動強度 $I_{0}$ を 1 として規格化した。 Fig. 1に即した ビームの配置にて，波長を $0.6 \mu \mathrm{m}$ ，ビームウエスト半径 $b$ を $5 \mathrm{~mm}$ と，送信点でのビームの等位相面の曲率半径 が十分に大きな，コリメート状の出射とした。送信端に 厚さ $\Delta z^{\prime}=100 \mathrm{~m}$ の薄層を置き，伝搬長 $z$ を $5 \mathrm{~km}$ とし，屈 折率摇らぎの最大サイズ(アウタースケール) $L_{0}$ を $1 \mathrm{~m}$ と した。数值積分における収束判定では相対誤差を100万 分の1以下に設定した。 


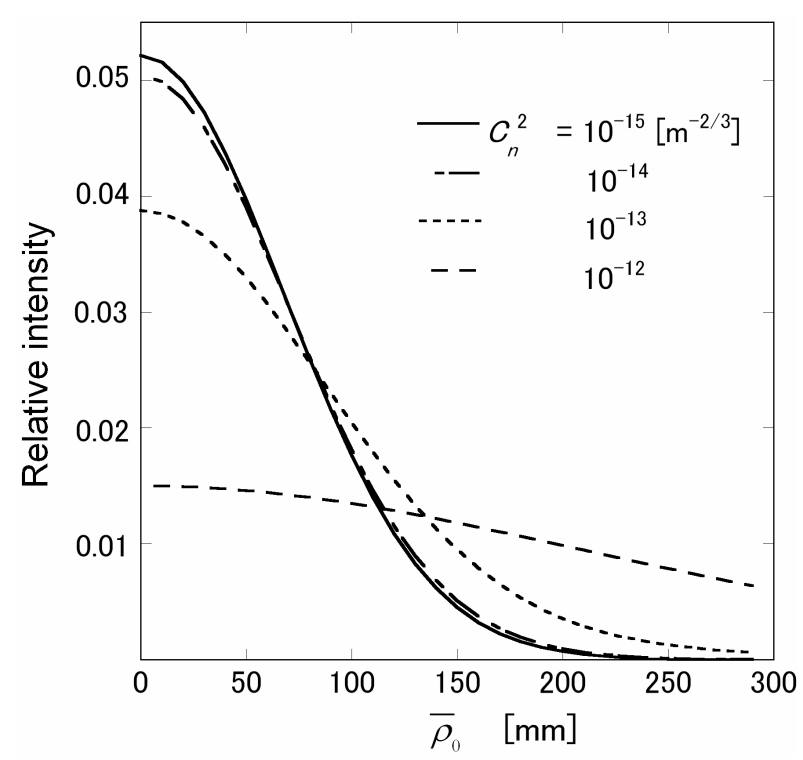

Fig. 2 Calculated intensity distribution of collimated beam wave propagated $5000 \mathrm{~m}$ with $5 \mathrm{~mm}$ beam waist radius as a function of $\bar{\rho}_{0}$ for several value of $C_{n}^{2}$ when $\lambda=0.6 \mu \mathrm{m}$ and $\Delta z^{\prime}=100 \mathrm{~m}$.

大気中の $C_{n}^{2}$ の一般的な值は $10^{-17}$ から $10^{-12} \mathrm{~m}^{-2 / 3}$ とされ ており, Fig. 2では $C_{n}^{2}$ の増加に伴いビームパターンの ピーク強度が低下するとともにパターンの裙が広がる妥 当な結果となった。なお，強い摇らぎの場合において も, 波動強度の1次モーメントはRytov法を含めて摇動の 解析手法に依らず同様な結果が得られる ${ }^{19)}$.

3.2 シンチレーションインデックスのビーム径依存 性

ビーム光軸上 $\left(\bar{\rho}_{0}=0\right)$ の波動強度 2 次モーメントの積分 表示である式(32)に対して極座標変換を施し, 数值計算 での4重積分に掛る時間を短縮させた。伝搬路の摇らぎ 強度を表す変数 $\eta$ に対するGaussianビームのシンチレー ションインデックス $\sigma_{I}^{2}$ をFig. 3に示す. 波長 $0.6 \mu \mathrm{m} の$ ビームをコリメート伝送し， $\Delta z^{\prime}=50 \mathrm{~m}$ の薄層を送信端 に設置し，伝搬長 $z$ を $5 \mathrm{~km}$ とた。. Fresnelサイズ $(\lambda z)^{1 / 2}$ の $(1 / 2 \pi)^{1 / 2}$ 倍を基準として, $b$ を $(\lambda z / 2 \pi)^{1 / 2}$ の1/4倍から約 200倍までの7值に設定したときの $\sigma_{I}^{2}$ を図示した。各曲 線に対して，bの值が大きい順にNo. 1からNo.7までと符 合した， $\eta$ に対する変化の様子を明瞭にするために実線 と点線を用いて描き，また，先行文献との対比のため両 軸を線形にて表示した。数值計算手法の検証として, $b \simeq 200(\lambda z / 2 \pi)^{1 / 2}$ と出射径が十分に大きく, 平面波と見 做せる場合の結果が飽和の後に 1 に漸近する形状を示し， 文献16），および，文献18）での計算結果との類似を確認 した.

Fig. 3に示した結果では, $b$ とFresnelサイズの大小関係 により曲線の形状が変化し, 飽和を与える している。 $\eta$ の範囲の制限からピークを示していない曲 線(No. 2, 5〜7)については, 数值計算により強度分散

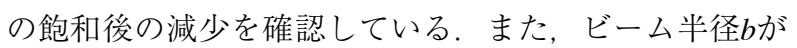
Fresnelサイズの $(1 / 2 \pi)^{1 / 2}$ 倍の付近にて, $\sigma_{I}^{2}$ が全体的に大

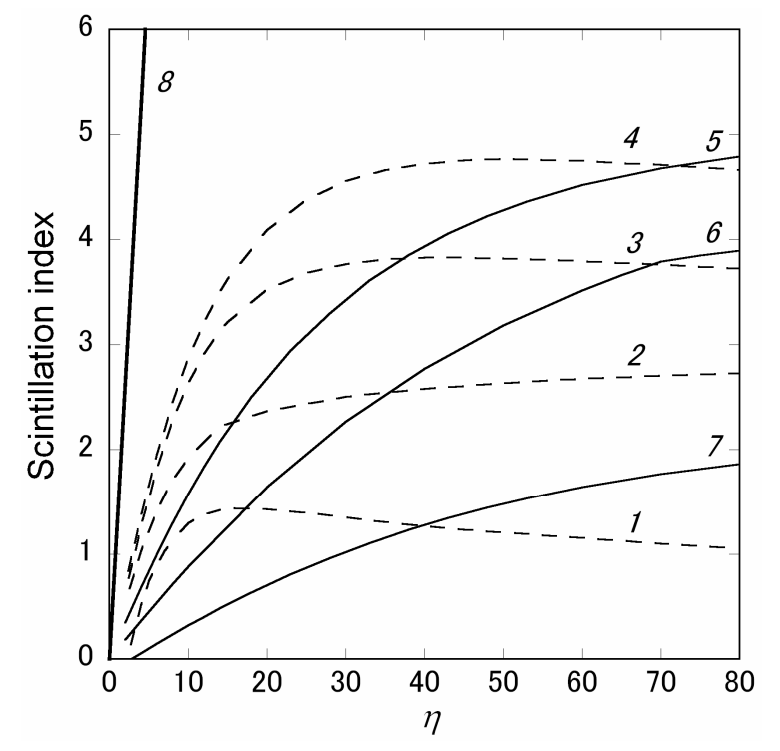

Fig. 3 Calculated scintillation index of collimated beam wave propagated $5000 \mathrm{~m}$ as a function of $\eta=$ $1.46 C_{n}^{2} k^{1 / 3}\left(2 \pi k z^{\prime}\right)^{5 / 6} \Delta z^{\prime}$ when $\lambda=0.6 \mu \mathrm{m}$ and $\Delta z^{\prime}=$ $50 \mathrm{~m}$. Beam radius $b$ is about 200 times of $(\lambda z / 2 \pi)^{1 / 2}$ for the dashed curve No. 1, and 4, 2, 1, $1 / 2,1 / 3$, and $1 / 4$ times of $(\lambda z / 2 \pi)^{1 / 2}$ for curves No. 2 to 7 . The bold curve no. 8 is a result calculated using the Rytov approximation analysis.

きい傾向となった。これは，薄層で受けた位相摇らぎに よって受光面上にて干渉が生じ，それによる強度分散が $b=(\lambda z / 2 \pi)^{1 / 2}$ のときに最も大きいことを示している. 平 面波の場合に，摇動への寄与が最大となる媒質摇らぎの 大きさがFresnelサイズと等しいことをCliffordが報告して おり ${ }^{21)}$ ，Fig. 3の結果と相互に関係した現象と言える.

本論では, 数值計算時間の制限から, 送信ビーム半径 が $(\lambda z / 2 \pi)^{1 / 2}$ の1/4倍より細いビームの結果は示せなかっ た. $\eta$ が 5 以下では, 被積分関数の指数関数項の減衰成分 が小さいことから，振動的な変化の残留により数值積分 が特に収束し難くなる。しかしながら， $b=(\lambda z / 2 \pi)^{1 / 2} / 4$ より細いビームの場合には, 曲線No. 5〜7の傾向から, $\eta$ 全般に渡り $\sigma_{I}^{2}$ が 0 以上で，かつ，曲線No.7を下回ると 推測している.

ビーム半径 $b=(\lambda z / 2 \pi)^{1 / 2}$ のときのRytov近似解法によ る薄層伝搬時の $\sigma_{I}^{2}$ の計算值をFig. 3に太線(曲線No. 8) に て書き入れた。この計算ではFig. 1に示したビームの配 置にて薄層を送信端に設定した。摂動解析であるRytov

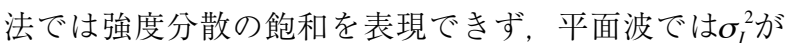
0.3 程度までがRytov法の適用可能な弱い摇らぎの状態と される ${ }^{19)}$. Rytov法と薄層近似を用いたモーメント法に よる両結果の乘離が $\eta$ の值とともに広がっており, Fig. 3 の左端の僅かな範囲においてRytov法が適用可能と言え る。参考として， $\eta$ に対する $C_{n}^{2}$ の值をFig. 4に示す。伝 搬長は500 m，5km，50kmの3ケースとし，薄層の厚さ は各伝搬長の $1 \%$ に設定した。 Fig. 4により，各伝搬長に 対して, Rytov近似によって弱い摇動として取り扱える 場合と, 強い摇動の解析が必要となる場合の $C_{n}^{2}$ が推量 できる，例えば，伝搬長 $5 \mathrm{~km}$ に対して $C_{n}{ }^{2}$ が $10^{-14} \mathrm{~m}^{-2 / 3}$ よ 


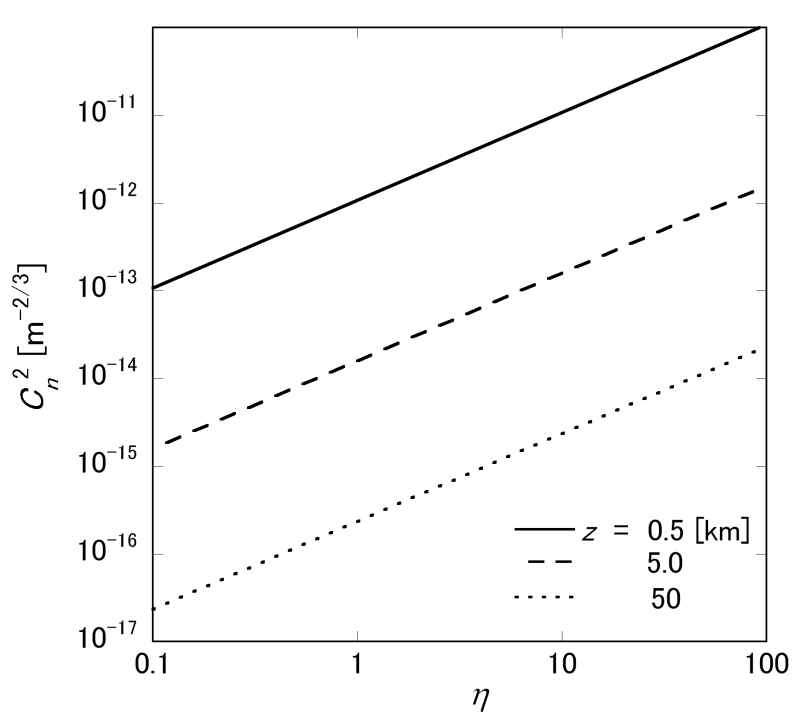

Fig. 4 Relation between refractive index structure constant $C_{n}^{2}$ and $\eta=1.46 C_{n}^{2} k^{1 / 3}\left(2 \pi k z^{\prime}\right)^{5 / 6} \Delta z^{\prime}$ with assumption of a thin phase screen turbulence when $z=0.5,5.0$, and $50 \mathrm{~km}$.

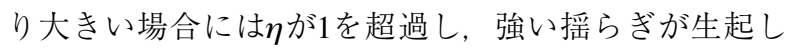
ていると考えられる.

\section{4. まとめ}

強い摇動でのビーム伝搬について，薄層近似による モーメント解を表し，それらを用いてビーム径を変えた 場合のシンチレーションインデックス $\sigma_{I}^{2}$ を数值計算に より求めた。ビーム径がFresnelサイズを跨ぐ各場合にお いて, 平面波の場合と同様に, $\eta$ の増加に伴い $\sigma_{I}^{2}$ が飽和 を示すことを確認した。 その中で本論の解析にて新たに 分かったことは, ビーム半径が $(\lambda z / 2 \pi)^{1 / 2}$ のときに, 飽 和時の $\sigma_{I}^{2}$ が最も大きな值を示したこと，および, ビー ム半径が $(\lambda z / 2 \pi)^{1 / 2}$ より細くなるに従い， $\sigma_{I}^{2}$ が低下する 傾向を示したことの2点である.

本論で取り扱った，ビーム伝搬の薄層近似を用いた モーメント解析は, 地上からのアップリンク等の惑星大 気の影響評価に直接適用できる解析法であり，ここで示 した $\sigma_{I}^{2}$ のビーム径依存性の結果が応用可能と考える.
薄層近似によるビーム摇動解析から全ての伝搬路にて大 気摇らぎが生起する場合への展開は必然であり，これま でにも，ビームが細い場合の近似），複数の薄層を仮定 する方法 ${ }^{22,23)}$, Two-scale 法 ${ }^{18,24,25)}$ 等による解析が行われ ており，それらについての評価検討は今後の報告に譲る こととする。しかしながら，式(19)に示したように，摇 らぎ媒質中の波動伝搬では，送信端での位相摇らぎが波 動強度2次モーメントに対して最も影響し易く，受光面 に近づくに連れてその寄与が弱まることから，薄層が送 信直後にある場合と一様な摇らぎ媒質が伝搬路に満たさ

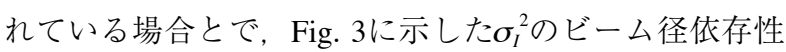
の傾向に本質的な差はないと考えている.

\section{参考文献}

1) V. I. Tatarski: Wave propagation in a turbulent medium (McGrawHill, New York, 1961).

2) T. Aruaga and S. W. Li: Appl. Opt. 38 (1999) 2795.

3) T. Shiina, K. Yoshida, M. Ito, and Y. Okamura: Opt. Commun. 279 (2007) 159.

4) A. Ishimaru: Proc. IEEE 65 (1977) 1030.

5) 豊田 雅宏：レーザー研究 38 (2010) 225.

6) K. Furutsu: J. Opt. Soc. Am. 62 (1972) 240.

7) R. L. Fante: Proc. IEEE 63 (1975) 1669.

8) R. H. Kleen and G. R. Ochs: J. Opt. Soc. Am. 60 (1970) 1695.

9) S. S. Khmelevtsov: Appl. Opt. 12 (1973) 2421.

10) A. M. Prokhorov, F. V. Bunkin, K. S. Gochelashvily, and V. I. Shishov: Proc. IEEE 63 (1975) 790.

11) A. Consortini, F. Cochetti, J. H. Churnside, and R. J. Hill: J. Opt. Soc. Am. A 10 (1993) 2354.

12) F. S. Vetelino, B. Clare, K. Corbett, C. Young, K. Grant, and L. Andrews: Appl. Opt. 45 (2006) 3534.

13) R. Mazer and A. Bronshtein: Opt. Commun. 75 (1990) 365.

14) Y. Furuhama: Radio Science 11 (1976) 763

15) M. Marians: Radio Science 10 (1975) 115.

16) Y. Furuhama: Radio Science 10 (1975) 1037.

17) V. I. Tatarskii: The effects of the turbulent atmosphere on wave propagation (U. S. Dept. of Commerce National Technical Information Service, Springfield, 1971).

18) K. Furutsu: Appl. Opt. 27 (1988) 2127.

19) J. W. Goodman: Statistical optics (Wiley, New York, 1985).

20) W. P. Brown Jr.: J. Opt. Soc. Am. 62 (1972) 966.

21) S. F. Clifford: Opt. Quant. Electron. 8 (1976) 95.

22) S. M. Flatté and J. S. Gerber: J. Opt. Soc. Am. 17 (2000) 1092.

23) R. Frehlich: Appl. Opt. 39 (2000) 393.

24) K. Furutsu and S. Ito: Appl. Opt. 32 (1993) 7512.

25) A. M. Whitman and M. J. Beran: J. Opt. Soc. Am. A 9 (1992) 974. 